\title{
Metabolic syndrome and Framingham risk score in obese young adults
}

\author{
Felix F. Widjaja, ${ }^{1}$ Ivan R. Widjaja, ${ }^{2}$ Yuni Astria,${ }^{1}$ Christopher S. Suwita, ${ }^{1}$ Sarwono Waspadji ${ }^{3}$ \\ ${ }^{1}$ Faculty of Medicine, Universitas Indonesia, Jakarta, Indonesia \\ ${ }^{2}$ Department of Child Health, Faculty of Medicine, Universitas Indonesia, Jakarta, Indonesia \\ ${ }^{3}$ Department of Internal Medicine, Faculty of Medicine, Universitas Indonesia, Jakarta, Indonesia
}

\begin{abstract}
Abstrak
Latar belakang: Peningkatan jumlah sindrom metabolik (MetS) pada dewasa muda sebagian besar disebabkan karena obesitas. MetS meningkatkan risiko penyakit jantung koroner (PJK) yang dapat diperkirakan dengan menggunakan Framingham risk score (FRS). Penelitian ini bertujuan untuk mengetahui prevalensi MetS dan FRS pada dewasa muda dengan obesitas dan hubungan keduanya dengan komponen MetS.
\end{abstract}

Metode: Tujuh puluh mahasiswa dan mahasiswi yang berumur $18-25$ tahun dengan IMT $\geq 25 \mathrm{~kg} / \mathrm{m}^{2}$ di Fakultas Kedokteran Universitas Indonesia dipilih secara konsekutif. Spesimen darah yang digunakan untuk memeriksa glukosa darah puasa, kolesterol total, high-density lipoprotein dan trigliserida dianalisis di Departemen Patologi Klinik RSUPN Cipto Mangunkusumo setelah puasa selama 14-16 jam. MetS didiagnosis dengan definisi International Diabetes Federation (IDF). Analisi univariat dan bivariat dilakukan pada penelitian.

Hasil: Prevalensi MetS berdasarkan definisi IDF adalah 18,5\% pada dewasa muda dengan obesitas. Komponen MetSyang paling berhubungan dengan MetS adalah hipertrigliseridemia (OR 12,13; 95\% CI 2,92-50,46; $p=0,001)$, tekanan darah tinggi (OR 9,33; 95\% CI 2,26-38,56; $p=0,001)$, HDL rendah (OR 8,33; 95\% CI 2,17-32,05; $p=0,003)$, and glukosa puasa terganggu $(p=0,03)$. Empat subjek mempunyai FRS $\geq 1 \%$ dan 66 subjek berisiko $<1 \%$. Peningkatan FRS tidak berhubungan dengan MetS $(p=0,154)$. Tidak ada komponen MetS berhubungan dengan peningkatan FRS.

Kesimpulan: Prevalensi MetS pada dewasa muda dengan obesitas hampir sama dengan pada anak-anak dan remaja dengan obesitas. Walaupun tidak didapatkan hubungan antara MetS dan FRS, keduanya merupakan prediktor penting untuk penyakit jantung koroner yang sebaiknya tidak digunakan secara terpisah. (Med $\mathbf{J}$ Indones. 2013;22:100-6)

\begin{abstract}
Background: The increase number of the metabolic syndrome (MetS) among young adults was mostly caused by obesity. MetS increases the risk of coronary heart disease (CHD) which can be estimated by Framingham risk score (FRS). The study was aimed to know the prevalence of MetS and FRS in obese young adults and to associate them with the components of MetS.

Methods: A total of 70 male and female students aged 18 to 25 years with $B M I \geq 25 \mathrm{~kg} / \mathrm{m}^{2}$ in Faculty of Medicine Universitas Indonesia were selected consecutively. The blood samples used to test fasting blood glucose, total cholesterol, high-density lipoprotein, and triglyceride were examined in Department of Clinical Pathology, Cipto Mangunkusumo Hospital after fasting for 14 to 16 hours. International Diabetes Federation (IDF) definition was used to diagnose MetS. Univariate and bivariate analysis were done.

Results: The prevalence of MetS based on IDF definition was 18.6\% among obese young adults. The most associated MetS components was hypertriglyceridemia (OR 12.13; 95\% CI 2.92-50.46; $\mathrm{p}=0.001$ ), followed with high blood pressure (OR 9.33; 95\% CI 2.26-38.56; $\mathrm{p}=0.001$ ), low-HDL (OR 8.33; 95\% CI 2.17-32.05; $\mathrm{p}=0.003$ ), and impaired fasting glucose $(\mathrm{p}=0.03)$. Four subjects had FRS $\geq 1 \%$ and 66 subjects had risk $<1 \%$. Increased FRS was not associated with MetS $(p=0.154)$. There was no component of MetS associated with increased FRS.

Conclusion: Prevalence of MetS in obese young adults was similar with obese children and adolescents. Although no association of MetS and FRS was found, they are significant predictors for CHD which should not be used separately. (Med J Indones. 2013;22:100-6)
\end{abstract}

Keywords: Abdominal obesity, Framingham risk score, metabolic syndrome, young adults

Metabolic syndrome (MetS) is a constellation of all metabolic risk factors comprised of: 1) atherogenic dyslipidemia (high serum triglycerides, Apolipoprotein-B, low-density lipoprotein/LDL, and low high-density lipoprotein/HDL); 2) elevated blood pressure; 3) elevated glucose associated with insulin resistance; 4) pro-thrombotic state; and 5) pro-inflammatory state. ${ }^{1}$ There are a lot of criteria for diagnosing MetS. In our research, we employed definition from International Diabetes Federation (IDF), which consists of central obesity, impaired fasting glucose, hypertriglyceridemia, low HDL, and hypertension.

The MetS may increase pro-inflammatory adipocyte products such as non-esterified fatty acids (NEFAs), inflammatory cytokines, and plasminogen-activator inhibitor-1 (PAI-1). Moreover, it may decrease the anti-inflammatory products: adiponectin, leptin, and resistin. The excess of NEFAs generates insulin resistance of the muscle and liver cells and atheroma 
production by increasing synthesis of triglycerides and forming fatty liver. Inflammatory cytokines alter the insulin secretion signal in pancreas and augment atherogenic macrophage. PAI- 1 contributes to pro-thrombotic state of the vascular system. The reduced adiponectin will tip the balance further into the pro-inflammatory state. In consequence, the cardiovascular system will become more vulnerable to coronary heart disease, stroke, thrombosis, lung emboli, and others. ${ }^{2,3}$

There are many tools that may help assessing coronary heart diseases (CHD) risks, such as Framingham, ${ }^{4}$ JBS, ${ }^{5}$ ASSIGN,${ }^{6}$ and QRISK. ${ }^{7}$ Those tools were studied in limited population (one country) ${ }^{8}$ which is a reason why Framingham equations predict the degree of risk less well in men and women younger than age 30, Japanese-American men, Hispanic men and NativeAmerican women. ${ }^{9}$ Framingham risk score (FRS) describes 10 year-CHD risks with several criteria of MetS included, such as: total cholesterol, systolic and diastolic blood pressure, and sex (for age). ${ }^{4}$ FRS has been proven helpful to predict the occurrence of primary coronary heart disease (CHD) with sensitivity and specificity of $56.5 \%$ and $75 \%$, respectively. ${ }^{10}$ Moreover, it is used to calculate absolute risk of CHD in patients without previous history of CHD, stroke, and peripheral vascular disease. ${ }^{9}$

Obesity is a state of excess body fat. Measurement of obesity can be done in several ways. Two wellaccepted methods in general practice are BMI $\left(\mathrm{kg} / \mathrm{m}^{2}\right)$ and waist circumference. Cut-off points for BMI and waist circumference are very much dependent on particular population. In this research we use Asian population classification for obesity and abdominal obesity. ${ }^{11}$

It is ironic that substantial expansion of technology has fashioned a lot of people to become more sedentary. Sedentary lifestyle is directly related to the occurrence of obesity. In Asia-Pacific regions, the prevalence of obesity in young adults (18-40 years old) increases by $2 \%$ per year. ${ }^{11,12}$ Researches from various centers also show the growing trend of CHD in young adults who are supposed to be in active age. ${ }^{12}$ Together with other emerging risk factors (dyslipidemia, hyperglycemia, hypertension, endothelial dysfunction, and insulin resistance), obesity play a great role in development of various metabolic and CHD including MetS. ${ }^{13}$ Obesity with fat excess also causes insulin resistance. On the other hand, insulin resistance worsens the adverse effects caused by obesity. This vicious cycle in turn will increase the risk for CHD. ${ }^{2}$
The substantial increase in the prevalence of the MetS in healthy young adults is driven mostly by the increase in obesity. ${ }^{14}$ Weiss et a ${ }^{15}$ also stated that the prevalence has become a burden among obese subjects and increased with worsening obesity. Biomarkers for risk of CHD have already been present even in young age. Many reports also point out that the presence of MetS contributes to the increased risk for CHD and type-2 diabetes. MetS will amplify the risk of CHD by two-fold and the risk of diabetes by five-fold. ${ }^{16,17}$ Moreover, diabetes will enhance the risk of CHD by three-fold and once a person conflicted both diseases, the prognosis will be significantly reduced. ${ }^{3}$

Therefore it is very important that prediction, or even diagnosis, of MetS and FRS in obese young adults be made as soon as possible to allow specific prevention and/or management according to risk factors. Our objectives were to identify the prevalence of MetS, FRS, and to know the relationship between them in obese young adults. We hope that this study could be regarded as a stepping stone for making public health policy.

\section{METHODS}

This cross-sectional study was held in the Faculty of Medicine Universitas Indonesia between April 2009 and April 2011. According to U.S. Department of Health and Human Services, ${ }^{18}$ young adults are people within 18 to 25 years old. We applied obese criteria from Asia Pacific, which defines BMI as $\geq 25 \mathrm{~kg} / \mathrm{m}^{2} .{ }^{11}$ The subjects were selected consecutively.

At the first meeting, we measured weight, height, waist circumference, and blood pressure with appropriate measurement methods (Table 1). All subjects that fit in the inclusion criteria were included. Those who matched one or more exclusion criteria (having a fever, in pregnancy, and/or suffering from malignancy) were excluded. They also filled some questionnaires for FRS data.

Calculation of FRS was done from NCEP-ATP III. ${ }^{4}$ FRS were calculated based on age, gender, total cholesterol, HDL-cholesterol, smoker, and systolic blood pressure or currently on any medication to treat high blood pressure. It classified the age from 20 to 34 years-old groups. In our study for FRS calculation, subjects who were less than 20 years old were considered as 20 years of age. We did a one-month recall of smoking. The subjects were considered as smokers if at least they smoked three cigarettes a week.

We recruited 80 subjects of which 70 subjects were examined. The subjects were then asked to fast about 14 to 16 hours. After that, blood samples were 
Table 1. Data measured and measurement method

\begin{tabular}{ll}
\hline Data measured & Measurement method \\
\hline Body weight & $\begin{array}{l}\text { Body weight was measured using Omron®Karada Scan digital body scale HBF-356 model with } 0.1 \mathrm{~kg} \\
\text { precision; the subjects stepped into the scale without any footwear or other accessories except their light } \\
\text { clothing. }\end{array}$ \\
Body height & $\begin{array}{l}\text { Body height was measured using microtoise with } 0.1 \mathrm{~cm} \text { precision; the subjects stand erect on flat floor } \\
\text { without any footwear or headgear, toe-to-toe, heels and spine are right next to the wall. }\end{array}$ \\
Waist circumference & $\begin{array}{l}\text { Waist circumference was measured using measuring tape with 0.1 cm precision; the measuring tape is } \\
\text { wrapped on the pelvic bone/iliac crest parallel to the floor regardless of the navel location at the time of } \\
\text { normal expiration. }\end{array}$ \\
& $\begin{array}{l}\text { Blood pressure was measured using mercury sphygmomanometer with } 1 \text { mmHg precision and a binaural } \\
\text { stethoscope; the measurements take place on the resting subjects' brachial artery using Korotkoff method, } \\
\text { which measure systole in Korotkoff sound I and diastole in Korotkoff sound V. }\end{array}$ \\
\hline
\end{tabular}

drawn and checked for fasting blood glucose, total cholesterol, high-density lipoprotein, and triglyceride blood level in Department of Clinical Pathology Cipto Mangunkusumo Hospital (RSCM).

The MetS was diagnosed with the criteria from IDF. They are central obesity (waist circumference $\geq 90 \mathrm{~cm}$ for men and $\geq 80 \mathrm{~cm}$ for women) plus two/more other clinical findings: 1) Fasting blood glucose $\geq 100 \mathrm{mg} / \mathrm{dL}$ or consuming glucose-lowering drugs; 2) triglyceride level in blood $\geq 150 \mathrm{mg} / \mathrm{dL}$ or consuming triglyceridelowering drugs; 3) $\mathrm{HDL}<40 \mathrm{mg} / \mathrm{dL}$ for men and $<$ $50 \mathrm{mg} / \mathrm{dL}$ for women; and 4) systolic blood pressure $\geq$ $130 \mathrm{mmHg}$ or diastolic blood pressure $\geq 85 \mathrm{mmHg}$ or consuming blood pressure-lowering drugs. ${ }^{19}$

All subjects signed informed consent and this protocol was approved by the Ethic Committee from Faculty of Medicine Universitas Indonesia. The collected or processed data were kept confidential.

Descriptive data were showed in frequencies; means and standard deviations for data with normal distribution; median, minimum, and maximum if data were not normally distributed. In the analysis, odds ratios were calculated between MetS components with MetS and FRS category. We categorized FRS into $<1 \%$ and $\geq$ $1 \%$ and only subjects that has abdominal obesity were included in the MetS components and FRS category analysis. Then, chi-square analysis, with Fisher as the alternative, was used to examine the association for categorical variables. Data were analyzed with SPSS ${ }^{\circledR}$ for Windows version 17.

\section{RESULTS}

A total of 70 subjects attended the examination process in Clinical Pathology RSCM Laboratory. Fifty one of the participants $(72.9 \%)$ were male. None of the subjects had diabetes or consumed cholesterol lowering-drugs. Only one subject consumed anti-hypertensive drugs. Thirty-five subjects had family history of diabetes and three subjects were smoking. Table 2 shows the central tendency of age, triglyceride, fasting blood glucose, HDL-cholesterol, waist circumference, BMI, and total cholesterol.

Table 2. Central tendency of variables

\begin{tabular}{ll}
\hline Variables & Central tendency \\
\hline Age & $20(18 ; 24)$ \\
Triglyceride & $84(37 ; 219)$ \\
Fasting blood glucose & $83.5(72 ; 117)$ \\
HDL-cholesterol & $49.17 \pm 10.61$ \\
Waist circumference & $95.75(78 ; 135)$ \\
BMI & $28.54(25.08 ; 40.4)$ \\
Total cholesterol & $173.23 \pm 34.94$ \\
\hline
\end{tabular}

Using the IDF criteria, the prevalence of MetS was $18.6 \%$. Twelve of them were male and there was no association between gender and MetS $(\mathrm{p}=0.097)$. Hypertriglyceridemia (OR 12.13; 95\% CI 2.92-50.46; $\mathrm{p}=0.001$ ) was likely to be more associated with MetS than high blood pressure (OR 9.33; 95\% CI 2.26-38.56; $\mathrm{p}=0.001)$ and low-HDL (OR 8.33; 95\% CI 2.17-32.05; $\mathrm{p}=0.003$ ). From 70 subjects, two subjects had impaired fasting glucose and both of them had also MetS; there were relationship between the two disorders $(p=0.03)$ but OR could not be calculated.

FRS identified one subject each who had 1\%, 2\%, 3\% and $4 \%$ risk and others had risk $<1 \%$. Subsequently, FRS was categorized into $<1 \%$ and $\geq 1 \%$. We found two subjects who had FRS $\geq 1 \%$ and MetS. Increased FRS was not associated with MetS (OR 5; 95\% CI $0.63-39.4 ; \mathrm{p}=0.154)$. 
MetS components were also examined separately with FRS that had been categorized into $<1 \%$ and $\geq 1 \%$. Because abdominal obesity was the most influencing factor in MetS, the relationship and OR were calculated only in subjects with abdominal obesity. There were 60 subjects who had abdominal obesity, from whom we found no component associated with increased FRS (hypertriglyceridemia [OR 12.25; 95\%CI 0.99-151.36; $\mathrm{p}=0.069$ ], low-HDL [OR 2.09; 95\%CI, 0.17-25.19; $\mathrm{p}=0.495]$, high blood pressure [OR 3.18; 95\%CI 0.27-37.20; $\mathrm{p}=0.558$ ]). In addition, there was no relationship between impaired fasting glucose and FRS $(\mathrm{p}=0.724)$.

\section{DISCUSSION}

Since there are no definitive criteria for MetS, it is difficult to compare the prevalence of MetS objectively. The commonly used criteria were ATP $\mathrm{III}^{1}, \mathrm{WHO}^{1}, \mathrm{AACE}$ (American Association of Clinical Endocrinologists) ${ }^{1}$, EGIR (European Group for the Study of Insulin Resistance) $)^{20}$ and IDF. ${ }^{19}$ Moreover, comparing prevalence MetS in obese people is also problematical due to difference of the BMI cut-off for obesity among ethnics. In Asia-Pacific regions the cutoff was $25 \mathrm{~kg} / \mathrm{m}^{2}$, but in Western population the cut-off was $30 \mathrm{~kg} / \mathrm{m}^{2} .{ }^{11}$

Using IDF criteria, our study found prevalence of MetS was $18.6 \%$ in obese young adults. In Finland ${ }^{21}$ and US ${ }^{19}$ which apply IDF criteria, the prevalence was $55.4 \%$ and $65.1 \%$ in obese adults, respectively. Other studies reported prevalence of MetS using ATP III criteria was 56.1-64.2\% among obese US adults. ${ }^{19,22}$ In Asia, there are no specific data that explicitly show prevalence of MetS in obese adults. According to Nestel et $\mathrm{al}^{23}$ and Mohamud et $a l,{ }^{24}$ the prevalence of MetS using IDF criteria in Asian adults was 9.6-26.3\%. In Jakarta, 2006, the prevalence of this disorder with ATP III-modified Asian criteria was $28.4 \%$ in adults. ${ }^{25}$

The prevalence is seen greater in Western countries. It may be affected by the higher cut-off BMI to bring in obese group. Greater BMI may give rise to number of MetS. Pan et al showed the evidence in all races that the higher BMI the subjects had, the more prevalence of MetS would be found. ${ }^{26}$

Beside BMI, older age also increases the prevalence of MetS. The higher the age of the population, the higher the prevalence will be. ${ }^{19,24}$ But, Ford ${ }^{19}$ showed that the trend was only significant till 70 year-old population; after that age population, the prevalence did not remain higher. Compared to the prevalence of MetS in Bogor ${ }^{27}$ among obese adults (31-55 years old) which was
$36.2 \%$, our result showed lesser prevalence because our age group was lower. Conversely, compared to Jamaican $^{28}$ youths (18-20 years), of which prevalence was only $1.2 \%\left(B M I=23.08 \pm 5.09 \mathrm{~kg} / \mathrm{m}^{2}\right)$, our result was much higher because of higher age group and BMI (Table 2) in our study.

Our prevalence data was more similar with studies conducted to children and adolescent age group in Spain (18.5\%), Brazil (17.4\%), Italy (13.9\%), and France (10.9\%). China, in which people closely related with Indonesian, had the lowest prevalence of MetS $(10.3 \%)$ among obese children. ${ }^{29}$ The prevalence of young adults was similar with children and adolescents, because the age group followed right after adolescents.

In children and adolescents, the prevalence of MetS also depends on BMI. Wickham et $\mathrm{al}^{30}$ showed the prevalence of the disorder was $30.3 \%$ in obese adolescents with a BMI mean of $38.2 \pm 8.5 \mathrm{~kg} / \mathrm{m}^{2}$. Thus, to compare the prevalence of MetS, we need to consider the BMI and age groups. The higher the age group and/or BMI, the higher the prevalence will be.

Our study showed obese young adults who had hypertriglyceridemia or high blood pressure or low-HDL had 8-12 times higher risks of metabolic syndrome. It was thought due to the obesity-related insulin sensitivity impairment and was correlated with the degree of overweight. ${ }^{31}$ Ferrannini et al ${ }^{32}$ supported the data that obesity was significantly associated with reduction of insulin sensitivity.

In our study, FRS was found relatively low. From 70 obese young adults, only $6 \%$ of subjects had FRS $\geq$ $1 \%$ and the highest risk was $4 \%$. All were below $10 \%$ risk, categorized as low risk. ${ }^{33}$ The result was not different with Berry et $a^{34}$ who found the risk $<1 \%$ to $4 \%$ in 5154 subjects of $18-29$ years old population of which $51.4 \%$ of the subjects were obese. They did a cohort study and found 10-years-coronary heart disease mortality rate was $0.58 \%$.

FRS is heavily dependent on age. This dependence can be understood by looking at the score for age in group 20-34 years of age where they give a score of -7 and -9 for women and men, respectively. Consequently, it needs severe abnormality (total cholesterol, HDL, systolic blood pressure) to affect the score. This results in FRS tendency to underestimate cardiovascular events in young adults. ${ }^{35}$ Moreover, Lee et $\mathrm{al}^{36}$ in their retrospective study showed that sensitivity of FRS in identifying at least intermediate risk (10-years risk of cardiovascular events $\geq 10 \%$ ) was $37.0 \%$ in young patients $(<40$ years old $)$. 
Obese young adults who had hypertriglyceridemia were twelve times more likely to have higher FRS (OR 12.25; 95\%CI 0.99-151.36; $\mathrm{p}=0.069$ ), although it might not be significant because of limited subjects. This is supported by a study that showed elevated moderate hypertriglyceridemia and waist circumference in asymptomatic men increases the risk for CHD, although elevated cholesterol, elevated LDL-cholesterol and other traditional risk factors were absent. ${ }^{37}$ As hypertriglyceridemia was indirectly related with obesity (BMI), we propose that BMI would also associate with FRS. Ghandehari et $\mathrm{a}^{38}$ reported that FRS was significantly associated with BMI and abdominal obesity (waist circumference).

Our data showed that MetS was not associated with higher FRS $(p=0.154)$. We considered it was because of our in-adequate sample size and number of events. However, till now, there are still limited researches that relate MetS with FRS. Many of them compare each other to propose better cardiovascular prediction.

MetS increased the risk for CHD significantly. ${ }^{20,26}$ Higher FRS was also shown to have higher hazard ratio for $\mathrm{CHD} .{ }^{10,39}$ Although we did not find association between MetS and high FRS in obese people, we suggest that patients should be assessed with MetS and FRS in order to exclude the risks. Both might not relate to each other but they have been shown to be significant tools for CHD with their own disadvantages and advantages. ${ }^{10,40}$ Moreover, when used together, McNeill found that they would enhance the predictive value. $^{41}$

We found $100 \%$ subjects had $<10 \%$ risk in obese subjects with MetS. It was similar with study conducted in North-India, Bansal et a ${ }^{35}$ that found $95.9 \%$ subjects had $<10 \%$ risk in $\leq 38$ years old population. However, this data should not be interpreted that obese people who had MetS were harmless. FRS only predicts short term risk reduction ( $\leq 10$ years) whereas MetS is aimed at long-risk reduction mainly through lifestyle modification. ${ }^{41}$

With this data, we want to encourage people, particularly obese young adults, to change lifestyle immediately. Reinehr et $\mathrm{al}^{31}$ showed improvement of cardiovascular risk factors every BMI reduction in obese children and adolescents. This supported the view of intervening obesity as early as possible.

Because older age and higher BMI will bring increased risks not only in MetS but also FRS, we propose that intervention should be done as early as possible to avoid CHD using MetS and FRS. Insulin resistance becomes important link between MetS and FRS with obesity (BMI). Insulin resistance-related complications such as hypertriglyceridemia had been a high risk factor in our study for both MetS and FRS. The model of this proposal is showed in figure 1 .

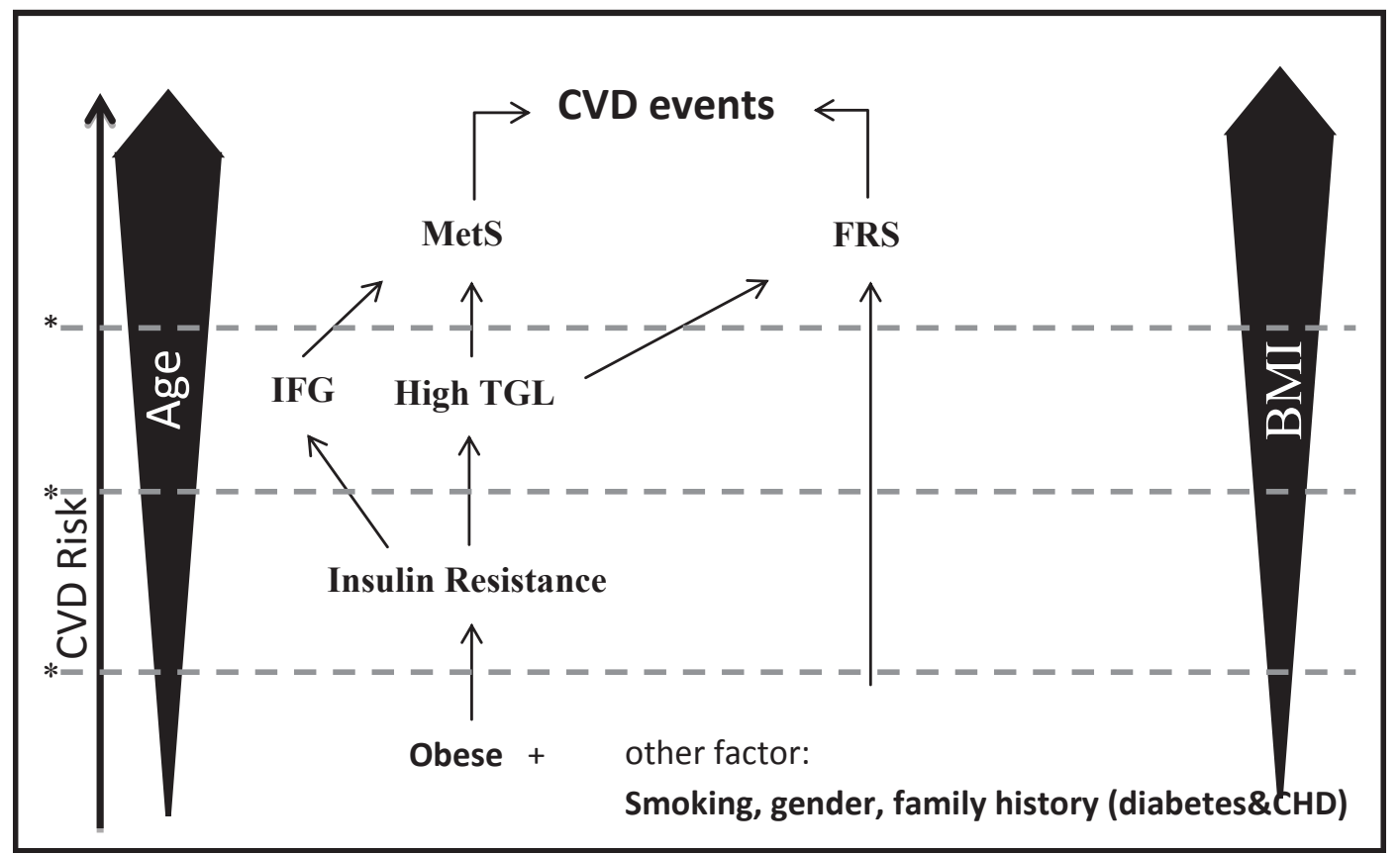

Figure 1. Model of metabolic syndrome and Framingham risk score that are age- and BMI-dependent in obese to CVD events. If the interventions (*) are done earlier, the CVD risk will also be lower. MetS: metabolic syndrome; FRS: Framingham risk score; IFG: impaired fasting glucose; TGL: triglyceride; CVD: cardiovascular disease; BMI: body mass index 
Several limitations of our study need to be considered. The cross-sectional and consecutive research limited us to assess the real mortality CHD event rate that should be examined with prospective cohort study. Moreover, the subjects and event groups of MetS and FRS were limited, so that we could not directly associate the age. The other drawback was insulin resistance was not checked, even though it is the important link between obesity with FRS and MetS. But, the strong point of our study is that it was done in obese young adults which was not commonly documented previously. Furthermore, young adults could have better results if intervention was done earlier.

In conclusion, prevalence of MetS in obese young adult was similar with prevalence of the disorder in obese children and adolescents because it was highly dependent on age. Hypertriglyceridemia had been prone to be high risk factor in our study for both MetS and FRS. It might be because hypertriglyceridemia is an insulin resistance-related complication which becomes important link between MetS and FRS with obesity (BMI).

In conclusion, although we found MetS and FRS were not associated with each other, MetS and FRS as significant predictors for CHD should not be used separately. Both predictors have their own strengths and weaknesses when used individually, hence it would be better for every patient to be taken with both approaches in assessing their CHD risks.

\section{Acknowledgments}

This study was supported by Faculty of Medicine Universitas Indonesia grant and PPKM Faculty of Medicine Universitas Indonesia.

\section{REFERENCES}

1. Grundy SM, Brewer HB, Jr., Cleeman JI, Smith SC, Jr., Lenfant C. Definition of metabolic syndrome: Report of the National Heart, Lung, and Blood Institute/American Heart Association conference on scientific issues related to definition. Circulation. 2004;109(3):433-8.

2. Einhorn D, Reaven GM, Cobin RH, et al. American College of Endocrinology position statement on the insulin resistance syndrome. Endocr Pract. 2003;9(3):237-52.

3. Isomaa $\mathrm{B}$, Almgren $\mathrm{P}$, Tuomi $\mathrm{T}$, et al. Cardiovascular morbidity and mortality associated with the metabolic syndrome. Diabetes Care. 2001;24(4):683-9.

4. Third Report of the National Cholesterol Education Program (NCEP) Expert Panel on Detection, Evaluation, and Treatment of High Blood Cholesterol in Adults (Adult Treatment Panel III) final report. Circulation. 2002;106(25):3143-421.
5. JBS 2: Joint British Societies' guidelines on prevention of cardiovascular disease in clinical practice. Heart. 2005;91 Suppl 5:v1-52.

6. Network SIG. Risk estimation and the prevention of cardiovascular disease: A national clinical guideline. Edinburgh: Scottish Intercollegiate Guidelines Network; 2007.

7. Hippisley-Cox J, Coupland C, Vinogradova Y, Robson J, May $\mathrm{M}$, Brindle P. Derivation and validation of QRISK, a new cardiovascular disease risk score for the United Kingdom: prospective open cohort study. BMJ. 2007;335:136.

8. Pocock SJ, McCormack V, Gueyffier F, Boutitie F, Fagard $\mathrm{RH}$, Boissel JP. A score for predicting risk of death from cardiovascular disease in adults with raised blood pressure, based on individual patient data from randomised controlled trials. BMJ. 2001;323:75-81.

9. Sheridan S, Pignone M, Mulrow C. Framingham-based tools to calculate the global risk of coronary heart disease: a systematic review of tools for clinicians. J Gen Intern Med. 2003;18(12):1039-52.

10. Wannamethee SG, Shaper AG, Lennon L, Morris RW. Metabolic syndrome vs Framingham Risk Score for prediction of coronary heart disease, stroke, and type 2 diabetes mellitus. Arch Intern Med. 2005;165(22):2644-50.

11. World Health Organization, International Obesity Task Force and International Association for the Study of Obesity. The Asia-Pacific Perspective: Redefining Obesity and its Treatment. Sydney: Health Communications Australia Pty Ltd; 2000.

12. Gortmaker SL, Must A, Perrin JM, Sobol AM, Dietz WH. Social and economic consequences of overweight in adolescence and young adulthood. N Engl J Med. 1993;329:1008-12.

13. Bosello O, Zamboni M. Visceral obesity and metabolic syndrome. Obes Rev. 2000;1(1):47-56.

14. Mattsson N, Ronnemaa T, Juonala M, Viikari JS, Raitakari OT. The prevalence of the metabolic syndrome in young adults. The Cardiovascular Risk in Young Finns Study. J Intern Med. 2007;261(2):159-69.

15. Weiss R, Dziura J, Burgert TS, et al. Obesity and the metabolic syndrome in children and adolescents. N Engl J Med. 2004;350:2362-74.

16. Alexander CM, Landsman PB, Teutsch SM, Haffner SM. NCEP-defined metabolic syndrome, diabetes, and prevalence of coronary heart disease among NHANES III participants age 50 years and older. Diabetes. 2003;52:1210-4.

17. Hunt KJ, Resendez RG, Williams K, Haffner SM, Stern MP. National Cholesterol Education Program versus World Health Organization metabolic syndrome in relation to all-cause and cardiovascular mortality in the San Antonio Heart Study. Circulation. 2004;110:1251-7.

18. U.S. Department of Health and Human Services: Substance Abuse and Mental Health Services Administration. National Household Survey on Drug Abuse: Main Findings 1996: Office of Applied Studies, Substance Abuse and Mental Health Service Administration, Department of Health \& Human Services; 1998.

19. Ford E. Prevalence of the metabolic syndrome defined by the International Diabetes Federation among adults in the U.S. Diabetes Care. 2005;28(11):2745-9.

20. Sarti C, Gallagher J. The metabolic syndrome: prevalence, CHD risk, and treatment. J Diabetes Complications. 2006;20(2):121-32. 
21. Mikkola I, Keinanen-Kiukaanniemi S, Laakso M, et al. Metabolic syndrome in connection with BMI in young Finnish male adults. Diabetes Res Clin Pract. 2007;76(3):404-9.

22. Ervin RB. Prevalence of metabolic syndrome among adults 20 years of age and over, by sex, age, race and ethnicity, and body mass index: United States, 2003-2006. National health statistics reports; no 13. Hyattsville MD: National Center for Health Statistics. 2009.

23. Nestel P, Lyu R, Low LP, et al. Metabolic syndrome: recent prevalence in East and Southeast Asian populations. Asia Pac J Clin Nutr. 2007;16(2):362-7.

24. Mohamud WN, Ismail AA, Sharifuddin A, et al. Prevalence of metabolic syndrome and its risk factors in adult Malaysians: results of a nationwide survey. Diabetes Res Clin Pract. 2011;91(2):239-45.

25. Soewondo P, Purnamasari D, Oemardi M, Waspadji S, Soegondo S. Prevalence of metabolic syndrome using NCEP/ATP III criteria in Jakarta, Indonesia: the Jakarta primary non-communicable disease risk factors surveillance 2006. Acta Med Indones. 2010;42(4):199-203.

26. Pan WH, Yeh WT, Weng LC. Epidemiology of metabolic syndrome in Asia. Asia Pac J Clin Nutr. 2008;17 Suppl $1: 37-42$.

27. Muherdiyantiningsih EF, Effendi R, Herman S. Sindrom metabolik pada orang dewasa gemuk di wilayah Bogor. Penel Gizi Makan. 2008;31:75-81. Indonesia.

28. Ferguson TS, Tulloch-Reid MK, Younger NO, et al. Prevalence of the metabolic syndrome and its components in relation to socioeconomic status among Jamaican young adults: a cross-sectional study. BMC Public Health. 2010;10:307.

29. Tailor AM, Peeters PH, Norat T, Vineis P, Romaguera D. An update on the prevalence of the metabolic syndrome in children and adolescents. Int J Pediatr Obes. 2010;5(3):202-13.

30. Wickham EP, Stern M, Evans RK, et al. Prevalence of the metabolic syndrome among obese adolescents enrolled in a multidisciplinary weight management program: clinical correlates and response to treatment. Metab Syndr Relat Disord. 2009;7(3):179-86.
31. Reinehr T, Kiess W, Kapellen T, Andler W. Insulin sensitivity among obese children and adolescents, according to degree of weight loss. Pediatrics. 2004;114(6):1569-73.

32. Ferrannini E, Natali A, Bell P, Cavallo-Perin P, Lalic N, Mingrone G. Insulin resistance and hypersecretion in obesity. European Group for the Study of Insulin Resistance (EGIR). J Clin Invest. 1997;100(5):1166-73.

33. Zannad F, Jakobsen A, Heroys J, Ralph A, Rees T, Shaw M. Cardiovascular high-risk patients--treat to protect, but whom? Medscape J Med. 2008;10 Suppl:S2.

34. Berry JD, Lloyd-Jones DM, Garside DB, Greenland P. Framingham risk score and prediction of coronary heart disease death in young men. Am Heart J. 2007;154(1):80-6.

35. Bansal M, Shrivastava S, Mehrotra R, Agarwal V, Kasliwal RR. Low Framingham risk score despite high prevalence of metabolic syndrome in asymptomatic North-Indian population. J Assoc Physicians India. 2009;57:17-22.

36. Lee GK, Lee LC, Liu CW, et al. Framingham risk score inadequately predicts cardiac risk in young patients presenting with a first myocardial infarction. Ann Acad Med Singapore. 2010;39(3):163-7.

37. Soegondo S. Atherogenic dyslipidemia and the metabolic syndrome. Acta Med Indones. 2005;37(3):177-83.

38. Ghandehari H, Le V, Kamal-Bahl S, Bassin SL, Wong ND. Abdominal obesity and the spectrum of global cardiometabolic risks in US adults. Int $\mathrm{J}$ Obes (Lond). 2009;33(2):239-48.

39. Jaquet A, Deloumeaux J, Dumoulin M, Bangou J, Donnet JP, Foucan L. Metabolic syndrome and Framingham risk score for prediction of cardiovascular events in Caribbean Indian patients with blood glucose abnormalities. Diabetes Metab. 2008;34(2):177-81.

40. Taslim S, Tai ES. The relevance of the metabolic syndrome. Ann Acad Med Singapore. 2009;38(1):25-9.

41. McNeill AM, Rosamond WD, Girman CJ, et al. The metabolic syndrome and 11-year risk of incident cardiovascular disease in the atherosclerosis risk in communities study. Diabetes Care. 2005;28(2):385-90. 